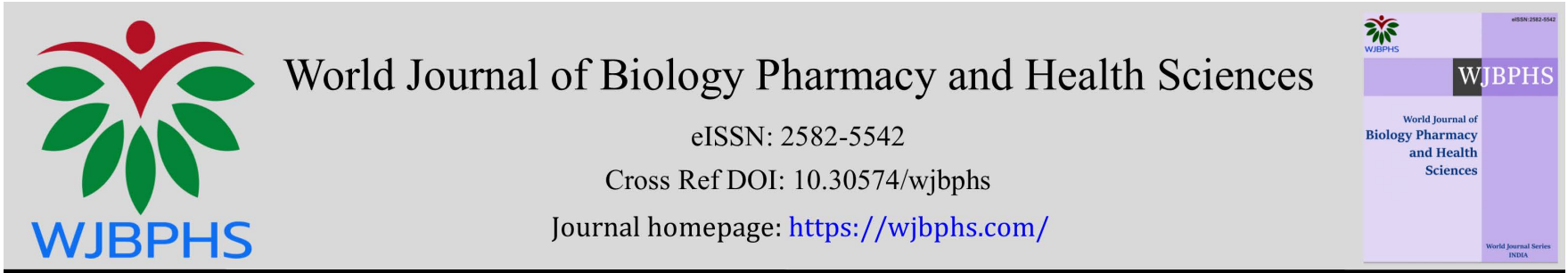

(RESEARCH ARTiCLE)

\title{
Prevalence and intensity of malaria infection and associated risk factors in Anambra State, Nigeria
}

\author{
Anaebonam Emeka 1, *, Eze Chinwe Catherine ${ }^{2}$, Okeke Chimaobi Emenike 1, Nweze Kenneth Emeka ${ }^{1}$ and \\ Okemadu Chimaobi Okemadu ${ }^{1}$ \\ ${ }^{1}$ Department of Biological Sciences, Chukwuemeka Odumegwu Ojukwu University, Anambra, Nigeria. \\ 2 Department of Microbiology, Federal University of Technology, Owerri, Nigeria.
}

World Journal of Biology Pharmacy and Health Sciences, 2021, 07(03), 030-045

Publication history: Received on 06 August 2021; revised on 08 September 2021; accepted on 10 September 2021

Article DOI: https://doi.org/10.30574/wjbphs.2021.7.3.0094

\begin{abstract}
The present study aimed at understanding the dynamics of malaria infection in Anambra State, Nigeria using sociodemographic risk factors, haematological and biochemical profile as well as knowledge, attitude and practice of respondents towards control of both infections. Participants were recruited using a systematic random sampling technique and a total of 2,550 subjects were enrolled for the study. The prevalence of malaria was determined using gold-standard - microscopy. The results revealed that 1,891 (72.4\%) out of the total subjects studied were malaria positive. The highest prevalence of malaria was recorded in Anambra North senatorial zone (75.0\%). Females presented with a higher rate of malaria infection with $77.9 \%$ prevalence than males with $70.0 \%$. Individuals who are $31-40$ years old had the highest malaria prevalence of 93.4\%. Traders and farmers had the highest malaria prevalence of $83.4 \%$. Participants with non-formal education had the highest malaria prevalence of $83.0 \%$. The prevalence of haematological and biochemical abnormalities were obtained from those infected with malaria only and were as followed: PCV 7.0\%, WBC $94.0 \%$, neutrophil 47.9\%, lymphocyte 33.7\%, eosinophil 56.6\%, monocyte 58.1\%, platelets $44.2 \%$, AST $23.1 \%$, ALT $31.7 \%$, ALP $26.6 \%$, glucose $37.8 \%$, protein $23.3 \%$, nitrite $14.7 \%$ and bilirubin $16.7 \%$. The highest drug of choice of the respondents was artemisinin combined therapy (ACT) (55.8\%). The four most important herbal remedies were: Azadiracta indica (71.7\%), Moringa oleifera (45.0\%), Allium sativum (44.0\%) and Zingibe officinale (40.0\%). The results highlight the need to prioritize educating the populace in future public health campaigns to increase knowledge and reduce misperception.
\end{abstract}

Keywords: Malaria; Prevalence; Risk-factors; Haematological; Biochemical profile

\section{Introduction}

Malaria is among the most debilitating diseases in the tropics and subtropics [1]. Malaria infection is endemic throughout much of tropical and sub-Saharan Africa and is a present major threat to public health [1]. This disease mostly occurs singly as mono-infection. Nigeria is endemic for malaria infection.

Malaria is caused by a single-celled protozoan parasite known as Plasmodium species transmitted from human to human through the bite of an infected female Anopheles mosquito. Presently, five Plasmodium species are known to infect man. These are P. falciparum, P. ovale, P. malariae, P. vivax, and P. knowlesi. P. knowlesi has been reported in parts of SouthEastern Asia where it is also known to cause malaria in monkeys [2]. The vector, the Anopheles mosquito transmits Plasmodia, which are contained in its saliva, into its host while obtaining a blood meal. Plasmodia enter circulating erythrocytes and feed on the haemoglobin and other proteins within the cells [3]. Ninety-seven countries and territories

\footnotetext{
* Corresponding author: Emeka Anaebonam

Department of Biological sciences, Chukwuemeka Odumegwu Ojukwu University, Uli, Anambra State Nigeria. 
in the world today are at risk of being infected with Plasmodium species. The WHO estimated that 300 - 500 million malaria cases occur annually with 2-3 million deaths per year [4]. Over $90 \%$ of all these deaths still occur in sub Saharan Africa. Although there has been a significant decline in malaria deaths from 985,000 in 2000 to 584,000 in 2013 with over 2 million cases, Africans still bear $80 \%$ of the global malaria burden [5]. A significant proportion of this burden lies in the Democratic Republic of Congo and Nigeria accounting for an estimated 40\% of deaths in 2012 [5].

Nigeria is reported to have an unenviable record of malaria, contributing about $25 \%$ of the world malaria burden [6]. At least $50.0 \%$ of her population suffers from at least one episode of malaria each year and $11.0 \%$ of maternal related mortality is attributed to malaria in pregnant women [7]. The Federal Ministry of Health [8] has noted that in Nigeria malaria leads to $25.0 \%$ of infant mortality (i.e. deaths in children aged $<1$ year) and $30.0 \%$ of childhood mortality. It is estimated that 300,000 deaths occur each year, $60.0 \%$ of outpatient visits to health facilities and $30.0 \%$ of hospitalizations are all attributable to malaria [9]. One hundred thirty-two billion Naira is said to be lost annually in Nigeria because of malaria (NMCP, 2017). The presence of malaria is a risk factor contributing to the prevalence of other infections or diseases [1]. Therefore, it imposes a great burden on the country in terms of pains and trauma suffered by its victims as well as loss in outputs and cost of treatments [10]. Such a high burden underscores the need for concerted efforts and interventions, all aimed at reversing the situation.

In a positive malaria patient, there may be abnormalities in the haematological parameters such as destruction of red blood cells, reduction in the percentage of packed cell volume (PCV) and haemoglobin (HB) amongst others [11], but the extent of haematological alterations varies with the level of malaria endemicity, background haemoglobinopathy, nutritional status, demographic factors and malaria immunity. Some risk factors of the malaria disease may include age, level of education, occupation and economic status amongst others [12] and [13]. In high transmission areas, partial immunity to the disease is acquired during childhood [14]. In such settings, the majority of malaria disease and particularly severe disease with rapid progression to death occurs in young children without acquired immunity. Severe anaemia, hypoglycaemia and cerebral malaria are features of severe malaria more commonly seen in malaria patients [15].

The diagnosis of malaria involves the identification of the parasites or parasite antigenic products in the blood of the patient. The efficacy of the diagnosis is subject to many factors. The different forms of schizogony, the endemicity of different species, immunity, parasitaemia, symptoms, and problems of recurrent malaria, drug resistance and the use of chemoprophylaxis or even presumptive treatment based on clinical diagnosis can all affect the identification and interpretation of malaria parasitaemia on diagnostic test [16].

Despite significant improvement in prevention and control over the past decades, malaria and other parasitic diseases remain a significant public health concern in Nigeria. To prevent malaria infection and promote malaria-free zones, understanding the community's knowledge, attitudes and practices towards malaria control are essential. Disease prevention is of prime importance in reducing the rate of morbidity and mortality, but everyday practice in households is related to local perception of risk and knowledge about malaria. Adequate community knowledge about malaria is crucial to guarantee that preventative measures are correctly applied and disease exposure is reduced. However, misconception about malaria frequently persists among communities and individual households that may jeopardize the success of disease prevention [17]. Therefore this study is aimed at understanding the dynamics of malaria infection in Anambra State, Nigeria using socio-demographic risk factors, haematological and biochemical profile as well as knowledge, attitude and practice of respondents towards control of both infections.

\section{Material and methods}

\subsection{Study Area}

The study was carried out in nine randomly selected health facilities in the three senatorial zones in Anambra State. The inhabitants of the study area are predominantly farmers, civil servants, students and traders. Some of the communities have perennial streams. Each of these streams has extensive freshwater swamps that serve as mosquito breeding sites. The samples collected were later taken to the laboratory for examination.

\subsection{Selection of the Health Facility}

Nine health facilities were randomly chosen from Anambra State based on their locations and attendance by the people. The basis of selection was one general hospital, one mission hospital and one private hospital from each of the senatorial zones in Anambra State. The selected health facilities were Chukwuemeka Odimegwu Ojukwu University Teaching Hospital (COOUTH) Awka, Nnamdi Azikiwe University Teaching Hospital (NAUTH) Nnewi, General Hospital Onitsha, 
General Hospital Agulu, Borromeo Hospital Onitsha, Waterside Hospital Onitsha, Our Lady of Lourdes Hospital Ihiala, Benedicts Memorial Hospital Onitsha and Reginal Caeli Hospital (RCH) Awka.

\subsection{Study Design}

The study design was a cross-sectional descriptive study carried out among a cohort of febrile subjects, attending hospitals in Anambra State, who gave their consent to participate in the study.

\subsection{Sample Population}

A total of 2,550 participants were recruited for the study. Sample selection was done using a combination of stratified and systematic random samplings. Villages in the communities were randomly selected using stratified random sampling technique whereas households in the villages were selected using a systematic random technique where one household was selected out of every ten households. Male and females were randomly selected from the selected households.

\subsection{Collection of Blood Sample}

The blood collection was done by trained nurses in all the health facilities. A total of 2,550 samples were collected for this study. The blood was transferred into an EDTA bottle to prevent agglutination. Serum samples kept in a freezer at $-70{ }^{\circ} \mathrm{C}$ were thawed at room temperature for 20 minutes before the assay procedure.

\subsection{Laboratory Examination of Malaria Parasite}

Microscopic examination of thick and thin blood films was adopted in this study for the diagnosis of malaria parasites [18].

\subsection{The procedure of Thick and Thin Blood Film}

This was done according to the method of Cheesbrough, [18].

\subsection{Microscopic Examination of the Blood Film}

A drop of immersion oil was placed on each air-dried slide and examined under the microscope using x100 objective lens. The presence of malaria parasites in the blood film was indicated by a positive sign (+), while the absence of malaria parasite was indicated by a negative sign (-).

\subsection{Determination of Intensity of Malaria}

This was also done following the method of Cheesbrough [18], the intensity of malaria parasites in the blood films was indicated with one or more positive signs as follows:

(a) Mild infection (+) for 1 - 10 parasites per 100 high power fields,

(b) Moderate infection (++) for 11 - 100 parasites per 100 high power fields,

(c) Heavy infection $(+++)$ for above 100 parasites per high power field.

\subsection{Determination of Haematological and Biochemical Parameter of the Subject}

\subsubsection{Determination of haematological parameter}

The determination of haematological parameters was analysed as described by Kolawole et al. [19] using an automated analysed (FBC DYMIND ANALYSER). The tests were done according to the instruction of the automatic multiparameter blood counter. The blood parameters investigated were full blood count and differential white blood cell count.

\subsection{Determination of Haematological and Biochemical Parameter of the Subject}

\subsubsection{Determination of haematological parameter}

The determination of haematological parameters such as packed cell volume (PCV) of the red blood cell, differential white blood cell count was analysed as described by Kolawole et al. [19] using an automated analyser (FBC DYMIND 
ANALYSER). The tests were done according to the instruction of the automatic multiparameter blood counter. The blood parameters investigated were full blood count and differential white blood cell count.

\subsubsection{Determination of biochemical parameter}

Biochemical parameters such as aspartate aminotransferase (AST), alanine aminotransferase (ALT), alkaline phosphatase (ALP), glucose, protein, nitrite and bilirubin were carried using an automated analyser (EMP Analyser) and kits from Inteco Diagnostics UK LTD.

\subsection{Determination of Knowledge, Attitude and Management Practice of Malaria}

These were investigated using in-depth interviews, focus group discussions and questionnaires.

In-depth interviews were held with medical doctors who have their hospitals in Anambra State, patent medicine dealers, other health practitioners, such as nurses, community health assistants, medical laboratory scientists and traditional healers (herbalists). This was used to obtain and elicit information on treatment-seeking behaviours of Anambra people about malaria infections.

\subsection{Administration of the structured questionnaire}

Questionnaires were employed in the study. A total of 2,000 pre-tested questionnaires were hand-delivered to individuals in Anambra State to obtain their knowledge, attitudes and practices on malaria. However, a total of 600 were duly completed and returned. This was achieved with the help of a guide/contact person. The answers given by illiterate subjects were filled in the forms using the assistance of the questionnaire administrator without any bias influencing their answers. The questionnaire consisted of questions divided into the following 5 sections: socio-demographic information (background history, age, sex, occupation, level of education), sources of information (media "radio, television, internet and press", training, other), knowledge about malaria (definition, signs and symptoms, transmission pathways, preventive measures), attitudes and practices regarding malaria and herbal remedies for malaria infections. The questionnaire was composed of close-ended questions that were either single or multiplechoice.

\subsection{Focus group discussion (FGD)}

This was used to validate responses received from questionnaires. Fifteen FGDs were held with men and women from different senatorial zones for the study (fifteen groups: five men groups, five women groups and five youth groups). The youth groups consist of post-primary school students, university undergraduates, graduates and apprentices aged 15 30 years old. The men and women groups consist of individuals from 30 years and above. Some of them are in various occupations such as teaching, petty trading, farming, civil servants and menial jobs. Some have no form of formal education while a few had tertiary education. The FGDs elicited information on their knowledge of causes, signs and symptoms, preventive strategies, attitudes and practices of malaria infection. These discussions were all recorded.

\subsection{Data Analysis}

All the data obtained were analysed using Statistical Package for Social Sciences (SPSS) software version 17.0. The relationship between the prevalence and intensity of the infection and various parameters obtained were analyzed. Chisquare test $\left(\mathrm{X}^{2}\right.$-test) and correlation analysis were used to compare the parameters. P-Value less than $0.05,(\mathrm{P}<0.05)$ was considered not significant.

\section{Results}

\subsection{Prevalence and Intensity of Malaria among the Studied Subject with Associated Risk Factor}

The result of 2,550 blood samples collected for malaria diagnosis from nine different health facilities in the study area was presented in Table 1. Of the 2,550 samples, 322 (12.6\%) was from COOUTH, Awka, 340 (13.3\%) from NAUTH, Nnewi, 300 (11.8\%) from General Hospital Onitsha, 162 (6.4\%) were from General Hospital Agulu, 290 (11.4\%) Borromeo Hospital Onitsha, 234 (9.2\%) Waterside Hospital Onitsha, 222 (8.7\%) from Our Lady of Lourdes Ihiala, 350 (13.7\%) from Benedicts' Memorial Hospital Agulu and 330 (12.9\%) from Regina Caeli Hospital Awka.

Of the 2,550 individuals tested for malaria from the 9 different health facilities in the study area, 1891 (74.2\%) were positive for malaria parasite (Table 1). The highest percentage prevalence of malaria (77.0\%) was recorded from Regina Caeli Hospital, Awka, followed closely by General Hospital, Onitsha where a prevalence of 76.0\% was recorded while 
the least prevalence of $61.7 \%$ was obtained from General Hospital, Agulu. The prevalence of malaria in other health facilities studied was as follows: 244 (75.8\%) from COOUTH, 256 (75.3\%) from NAUTH, Nnewi, 220 (75.9\%) from Borromeo Hospital, Onitsha, 168 (71.8\%) from Waterside Hospital, Onitsha, 156 (70.3) from Our Lady of Lourdes Hospital, Ihiala and 265 (75.7\%) from Benedicts' Memorial Hospital Onitsha. There was no significant differences (P > 0.05 ; Chi-square $=5.079$, P-value $=0.749$ ) in malaria prevalence in relation to the health facility .

Of all the 1891 (74.2\%) individuals infected with malaria, 1569 (83.0\%) had mild malaria infection, 224 (9.6\%) had a moderate infection, and $98(4.2 \%)$ had a heavy infection (Table 1). The highest prevalence of mild malaria (88.2\%) was recorded at Regina Caeli Hospital Awka, followed by General Hospital, Onitsha where a prevalence of $86.0 \%$ was obtained. The least prevalence of mild malaria (74.0\%) was recorded at General Hospital, Agulu. For moderate malaria, the highest prevalence (14.7\%) was recorded at Waterside Hospital, Onitsha, followed by General Hospital Agulu $(12.0 \%)$ while the least prevalence (7.2\%) was obtained from Regina Caeli Hospital, Awka. The highest prevalence (5.6\%) of heavy malaria was recorded at Borromeo Hospital, Onitsha, followed by General Hospital, Agulu (5.3\%). The least prevalence (2.6\%) was obtained from Regina Caeli Hospital, Awka. In COOUTH, $200(82.0 \%)$ had a mild infection, $32(10.9 \%)$ had a moderate infection while 12 (4.1\%) had a heavy infection. At NAUTH, Awka, 219 (85.5\%) had mild infection with malaria parasites, 27 (8.8\%) had moderate and 10 (3.3\%) had heavy infections. At General Hospital, Onitsha 196 (86.0\%) had mild malaria infection, 22 (7.9\%) had a moderate infection and 10 (3.6\%) had a heavy infection of malaria parasites. There was no significant differences $(\mathrm{P}>0.05$; Chi-square $=18.492 ; \mathrm{p}$-value $=0.296)$ in the intensity of malaria in relation to the health facilities.

Table 1 Prevalence and intensity of malaria in relation to health facility in Anambra State

\begin{tabular}{|l|c|c|c|c|c|}
\hline \multicolumn{1}{|c|}{ Health facility } & $\begin{array}{c}\text { No. } \\
\text { examined }\end{array}$ & $\begin{array}{c}\text { No. infected } \\
\text { (\%) }\end{array}$ & $\begin{array}{c}\text { Mildly } \\
\text { infected (\%) }\end{array}$ & $\begin{array}{c}\text { Moderately } \\
\text { infected (\%) }\end{array}$ & $\begin{array}{c}\text { Heavily } \\
\text { infected (\%) }\end{array}$ \\
\hline COOUTH Awka & $322(12.6)$ & $244(75.8)$ & $200(82.0)$ & $32(10.9)$ & $12(4.1)$ \\
\hline NAUTH Nnewi & $340(13.3)$ & $256(75.3)$ & $219(85.5)$ & $27(8.8)$ & $10(3.3)$ \\
\hline Gen. Hosp. Onitsha & $300(11.8)$ & $228(76.0)$ & $196(86.0)$ & $22(7.9)$ & $10(3.6)$ \\
\hline Gen Hosp. Agulu & $162(6.4)$ & $100(61.7)$ & $74(74.0)$ & $18(12.0)$ & $8(5.3)$ \\
\hline $\begin{array}{l}\text { Borromeo Hosp. } \\
\text { Onitsha }\end{array}$ & $290(11.4)$ & $220(75.9)$ & $185(84.1)$ & $20(7.4)$ & $15(5.6)$ \\
\hline $\begin{array}{l}\text { Waterside Hosp. } \\
\text { Onitsha }\end{array}$ & $234(9.2)$ & $168(71.8)$ & $126(75.0)$ & $32(14.7)$ & $10(4.6)$ \\
\hline $\begin{array}{l}\text { Our Lady of Lourdes } \\
\text { Hosp. Ihiala }\end{array}$ & $222(8.7)$ & $156(70.3)$ & $128(82.1)$ & $19(9.2)$ & $9(4.4)$ \\
\hline $\begin{array}{l}\text { Benedicts Mem. Hosp. } \\
\text { Onitsha }\end{array}$ & $350(13.7)$ & $265(75.7)$ & $217(81.9)$ & $32(10.2)$ & $16(5.1)$ \\
\hline $\begin{array}{l}\text { Regina Caeli Hosp. } \\
\text { Awka }\end{array}$ & $330(12.9)$ & $254(77.0)$ & $224(88.2)$ & $22(7.2)$ & $8(2.6)$ \\
\hline Total & $2550(100.0)$ & $1891(74.2)$ & $1569(83.0)$ & $224(11.8)$ & $98(5.2)$ \\
\hline
\end{tabular}

The prevalence and intensity of malaria in the senatorial zone are shown in Table 2 . Of the 2,550 participants, 1174 (46.0\%) were from Anambra North senatorial zone, 562 (22.1\%) were from Anambra South senatorial zone while 814 (31.9\%) were from Anambra Central senatorial zone. Of the 1,891 (74.2\%) malaria positive individuals, the highest prevalence of $75.0 \%$ was from the Anambra North Senatorial zone, followed by the Anambra Central senatorial zone with a prevalence of 73.5\% was recorded. The least prevalence (73.3\%) was obtained from Anambra South senatorial zone. There was no significant difference in relation to senatorial zone $(\mathrm{P}>0.05$; Chi-square $=0.628 ; \mathrm{P}$-value $=0.731)$.

The highest prevalence of mild malaria (86.3\%), occurred in Anambra North senatorial zone while the highest prevalence of moderate malaria (12.0\%) occurred in both Anambra North and Central senatorial zone. The highest prevalence of heavy malaria (5.8\%) occurred in Anambra North senatorial zone. Out of the 881 infected individuals from Anambra North senatorial zone, 760 (86.3\%) had a mild infection, $106(12.0 \%)$ had a moderate infection while 51 (5.8\%) had a heavy infection. Of 412 infected individuals from Anambra South senatorial zone, 302 (73.3\%) had a mild 
infection, $46(11.2 \%)$ had a moderate infection while 19 (4.6\%) had a heavy infection. For Anambra Central senatorial zone, out of 598 infected individuals, 507 (84.8\%) had mild malaria, 72 (12.0\%) had moderate malaria and 28 (4.6\%) had heavy malaria. There was a significant differences $(\mathrm{P}<0.05$; Chi-square $=14.160$; $\mathrm{p}$-value $=0.007)$ in the intensity of malaria in relation to senatorial zone.

Table 2 Prevalence and intensity of malaria in relation to senatorial zone in Anambra State

\begin{tabular}{|l|c|c|c|c|c|}
\hline Senatorial zone & No. examined & $\begin{array}{c}\text { No. infected } \\
\text { (\%) }\end{array}$ & $\begin{array}{c}\text { Mildly infected } \\
\text { (\%) }\end{array}$ & $\begin{array}{c}\text { Moderately } \\
\text { infected (\%) }\end{array}$ & $\begin{array}{c}\text { Heavily } \\
\text { infected (\%) }\end{array}$ \\
\hline Anambra North & $1174(46.0)$ & $881(75.0)$ & $760(86.3)$ & $106(12.0)$ & $51(5.8)$ \\
\hline Anambra South & $562(22.1)$ & $412(73.3)$ & $302(73.3)$ & $46(11.2)$ & $19(4.6)$ \\
\hline Anambra Central & $814(31.9)$ & $598(73.5)$ & $507(84.8)$ & $72(12.0)$ & $28(4.6)$ \\
\hline Total & $2,550(100.0)$ & $1,891(74.2)$ & $1,569(83.0)$ & $224(11.8)$ & $98(5.2)$ \\
\hline
\end{tabular}

Table 3 showed the prevalence and intensity of malaria in relation to gender in Anambra State. Out of the 1,891 (74.2\%) malaria positive individuals, $878(70.0 \%)$ were males while 1,013 (77.9\%) were females. There was a significant differences $(\mathrm{P}<0.05$; Chi-square $=14.700$; $\mathrm{p}$-value $=0.000)$ in the prevalence of malaria in relation to gender. Also, out of 878 infected males, $708(80.6 \%)$ had mild infection, $130(14.8 \%)$ had moderate infection while 40 (4.6\%) had heavy infection; while out of 1,013 infected females, $861(85.0 \%)$ had mild infection, $94(9.3 \%)$ had moderate infection while $58(5.7 \%)$ had heavy infection. There was significant differences $(P<0.05$; Chi-square $=16.220 ; p$-value $=0.000)$ in the intensity of malaria in relation to gender.

Table 3 Prevalence and intensity of malaria in relation to gender in Anambra State

\begin{tabular}{|l|c|c|c|c|c|}
\hline Gender & $\begin{array}{c}\text { No. } \\
\text { examined }\end{array}$ & $\begin{array}{c}\text { No. infected } \\
\text { (\%) }\end{array}$ & $\begin{array}{c}\text { Mildly infected } \\
\text { (\%) }\end{array}$ & $\begin{array}{c}\text { Moderately } \\
\text { infected (\%) }\end{array}$ & $\begin{array}{c}\text { Heavily } \\
\text { infected (\%) }\end{array}$ \\
\hline Male & $1,250(49.0)$ & $878(70.0)$ & $708(80.6)$ & $130(14.8)$ & $40(4.6)$ \\
\hline Female & $1,300(51.0)$ & $1,013(77.9)$ & $861(85.0)$ & $94(9.3)$ & $58(5.7)$ \\
\hline Total & $2,550(100.0)$ & $1,891(74.2)$ & $1,569(83.0)$ & $224(11.8)$ & $98(5.2)$ \\
\hline
\end{tabular}

Table 4 showed the prevalence and intensity of malaria to age in Anambra State. From the Table, three hundred and forty (340) (13.3\%) were in the age group of < 10 years, $375(14.7 \%)$ fell in the age group $11-20$ years, $530(20.8 \%)$ were in the age group 20 - 30 years, 335 (13.9\%) were in the age group 31 - 40 years, 350 (13.7\%) were in the age group 41 - 50 years, $330(12.9 \%)$ were in the age group 51 - 60 years and $290(11.4 \%)$ were in the age group 60 years and above.

The highest prevalence of malaria (93.4\%) in relation to age occurred among subjects in the age group 31 - 40 years, while the least prevalence (59.7\%) occurred among those more than 60 years old. Prevalence in other age groups were: $243(71.2 \%)$ in less than 10 years, $268(71.5 \%)$ in $11-20$ years, $417(78.7 \%)$ in 21 - 30 years, $244(69.7 \%)$ in $41-50$ years old, $233(70.6 \%)$ in 51 - 60 years old and $173(59.7 \%)$ in those aged 60 years and above. There was a significant differences $(\mathrm{P}<0.05$; Chi-square $=21.069 ; \mathrm{p}=0.000)$ in the prevalence of malaria infection in relation to age.

Also, out of the $243(71.2 \%)$ in the age group < 10 years old that had malaria, $194(79.8 \%)$ had mild malaria infection, $35(14.4 \%)$ had a moderate infection and 14 (5.8\%) had a heavy infection. In the age group 11- 20 years, 216 (80.6\%) had a mild infection, 40 (14.9\%) had a moderate infection and $12(4.5 \%)$ had a heavy infection of malaria parasites. In the age group 21 - 30 years old, 345 (82.7\%) had a mild infection, 52 (12.5\%) had a moderate infection and 20 (4.8\%) had a heavy infection. In the age group 31 - 40 years, 276 (88.2\%) had a mild infection, 24 (7.7\%) moderate and 13 $(4.2 \%)$ had a heavy infection. In the age group 41 - 50 years, $191(78.3 \%)$ had a mild infection, $38(15.6 \%)$ had moderate and $15(6.1 \%)$ had a heavy infection of malaria parasites. In the age group, 51 - 60 years, $184(79.0 \%)$ had mild infection, $35(15.0 \%)$ moderate infection and $14(6.0 \%)$ had heavy infection. Finally, in the age group 60 years and above, 143 
(82.7\%) had a mild infection, 20 (11.6\%) moderate and 10 (5.8\%) had heavy infections. There was no significant differences $(\mathrm{P}>0.05$; Chi-square $=5.887 ; \mathrm{p}=0.922)$ in the intensity of malaria infection in relation to age.

Table 4 Prevalence and intensity of malaria in relation to age in Anambra State

\begin{tabular}{|c|c|c|c|c|c|}
\hline Age (years) & $\begin{array}{c}\text { No. } \\
\text { examined }\end{array}$ & $\begin{array}{c}\text { No. infected } \\
(\mathbf{\% )}\end{array}$ & $\begin{array}{c}\text { Mildly infected } \\
\text { (\%) }\end{array}$ & $\begin{array}{c}\text { Moderately } \\
\text { infected (\%) }\end{array}$ & $\begin{array}{c}\text { Heavily } \\
\text { infected (\%) }\end{array}$ \\
\hline$<10$ & 340 & $243(71.2)$ & $194(79.8)$ & $35(14.4)$ & $14(5.8)$ \\
\hline $11-20$ & 375 & $268(71.5)$ & $216(80.6)$ & $40(14.9)$ & $12(4.5)$ \\
\hline $21-30$ & 530 & $417(78.7)$ & $345(82.7)$ & $52(12.5)$ & $20(4.8)$ \\
\hline $31-40$ & 335 & $313(93.4)$ & $276(88.2)$ & $24(7.7)$ & $13(4.2)$ \\
\hline $41-50$ & 350 & $244(69.7)$ & $191(78.3)$ & $38(15.6)$ & $15(6.1)$ \\
\hline $51-60$ & 330 & $233(70.6)$ & $184(79.0)$ & $35(15.0)$ & $14(6.0)$ \\
\hline $60+$ & 290 & $173(59.7)$ & $143(82.7)$ & $20(11.6)$ & $10(5.8)$ \\
\hline Total & 2,550 & $1,891(74.2)$ & $1,569(83.0)$ & $224(11.8)$ & $98(5.2)$ \\
\hline
\end{tabular}

Table 5 showed the prevalence and intensity of malaria to occupation in Anambra State. From the prevalence and intensity of malaria infection based on occupation, traders had the highest prevalence (83.4\%), followed by pupils/students (79.0\%) while artisans had the least (65.0\%). Farmers had a prevalence of 236 (71.1\%) and civil servants had a prevalence of 460 (66.4\%). However, civil servants and pupils/students had an almost equal prevalence of mild infection of $91.3 \%$ and $91.1 \%$, respectively, followed by traders (87.1\%). Surprisingly, the least prevalence was observed among the farmers (58.9\%). For moderate infection, the highest prevalence was recorded among the artisans $(29.7 \%)$ followed by farmers (25.8\%). The least prevalence was recorded among the civil servants (5.5\%). For heavy infection, the highest prevalence was observed among the farmers (15.3\%) while the least prevalence $(2.2 \%)$ was recorded among the civil servants. There was a significant differences $(\mathrm{P}<0.05$; Chi-square $=19.396 ; \mathrm{P}=0.000)$ in the prevalence and significant differences $(\mathrm{P}<0.05$; Chi-square $=156.068 ; \mathrm{P}=0.000)$ intensity of malaria infection by risk factors in relation to occupation.

Table 5 Prevalence and intensity of malaria in relation to occupation in Anambra State

\begin{tabular}{|l|c|c|c|c|c|}
\hline Occupation & No. examined & $\begin{array}{l}\text { No. infected } \\
\text { (\%) }\end{array}$ & $\begin{array}{l}\text { Mildly infected } \\
\text { (\%) }\end{array}$ & $\begin{array}{l}\text { Moderately } \\
\text { infected (\%) }\end{array}$ & $\begin{array}{l}\text { Heavily } \\
\text { infected (\%) }\end{array}$ \\
\hline Pupils/students & $500(19.6)$ & $395(79.0)$ & $360(91.1)$ & $25(6.3)$ & $10(2.5)$ \\
\hline Traders & $725(28.4)$ & $605(83.4)$ & $527(87.1)$ & $50(8.3)$ & $28(4.6)$ \\
\hline Farmers & $332(13.0)$ & $236(71.1)$ & $139(58.9)$ & $61(25.8)$ & $36(15.3)$ \\
\hline Civil Servants & $693(27.2)$ & $460(66.4)$ & $420(91.3)$ & $30(5.5)$ & $10(2.2)$ \\
\hline Artisans & $300(11.8)$ & $195(65.0)$ & $123(63.1)$ & $58(29.7)$ & $14(7.2)$ \\
\hline Total & $2,550(100.0)$ & $1,891(74.2)$ & $1,569(83.0)$ & $224(11.8)$ & $98(5.2)$ \\
\hline
\end{tabular}

Table 6 showed the prevalence and intensity of malaria to the level of literacy in Anambra State. From the table, the highest malaria prevalence (83.0\%) was recorded among those who had non - formal education and the least prevalence (59.1\%) was recorded among those who had degree/tertiary education. Those who had secondary/WASSCE education and primary/FSLC education had a prevalence of $65.3 \%$ and $66.3 \%$, respectively. There was a significant differences $(\mathrm{P}<0.05$; Chi-square $=20.814 ; \mathrm{p}=0.000)$ in the prevalence of malaria infection in relation to literacy level.

On the intensity of malaria, those who had non - formal education and primary/FSLC education had the highest prevalence of mild malaria (88.7\%) while the least prevalence of mild infection (51.0\%) was observed among those 
with secondary/WASSCE education. The highest prevalence of moderate malaria (38.5\%) was recorded among those with degree/tertiary education followed by those with secondary/WASSCE education (35.7\%). The least prevalence of moderate malaria was observed among those with non - formal education where a prevalence of $7.0 \%$ was obtained. The highest prevalence of heavy malaria was found among those with secondary/WASSCE education (10.3\%) followed by those with degree/tertiary education (9.2\%), while the least prevalence (3.8\%) was recorded among those with primary/FSLC education. There was a significant differences $(\mathrm{P}<0.05$; Chi-square $=159.662 ; \mathrm{P}<0.000)$ in the intensity of malaria infection in relation to education.

Table 6 Prevalence and intensity of malaria in relation to the level of literacy in Anambra State

\begin{tabular}{|l|l|l|c|c|c|}
\hline Level of literacy & $\begin{array}{l}\text { No. } \\
\text { examined }\end{array}$ & $\begin{array}{l}\text { No. infected } \\
\text { (\%) }\end{array}$ & $\begin{array}{l}\text { Mildly infected } \\
\text { (\%) }\end{array}$ & $\begin{array}{l}\text { Moderately } \\
\text { infected (\%) }\end{array}$ & $\begin{array}{l}\text { Heavily } \\
\text { infected (\%) }\end{array}$ \\
\hline Non - formal education & $1,350(53.0)$ & $1,121(83.0)$ & $994(88.7)$ & $78(7.0)$ & $52(4.6)$ \\
\hline Primary/FSLC education & $720(28.2)$ & $477(66.3)$ & $423(88.7)$ & $36(7.5)$ & $18(3.8)$ \\
\hline $\begin{array}{l}\text { Secondary/WASSCE } \\
\text { Education }\end{array}$ & $150(5.8)$ & $98(65.3)$ & $50(51.0)$ & $35(35.7)$ & $10(10.3)$ \\
\hline Degree/tertiary education & $330(13.0)$ & $195(59.1)$ & $102(52.3)$ & $75(38.5)$ & $18(9.2)$ \\
\hline Total & $2,550(100.0)$ & $1,891(74.2)$ & $1,569(83.0)$ & $224(11.8)$ & $98(5.2)$ \\
\hline
\end{tabular}

N.B: FSLC = First school leaving certificate; WASSCE = West African Senior School Certificate of Examination.

\subsection{Knowledge, Attitude and Practice Profile of Respondent on Malaria Infection}

Among the total of 1,000 respondents, 620 agreed to complete the survey and 600 forms were selected, which corresponds to a participation rate of $60.0 \%$. A total of 600 people participated in the study among whom 280 (46.7\%) were males and 320 (53.3\%) were females.

The respondents' responses about their knowledge of the malaria disease in the study area are shown in Table 7. All the $600(100.0 \%)$ respondents were aware of the malaria disease and said they had suffered from it. They also identified the local name of the malaria disease as "Iba". The perceptions of the respondents about malaria were statistically significant $(\mathrm{P}<0.05$; Chi-square $=416.334 ; \mathrm{P}<0.000)$.

Table 7 Knowledge of respondents about malaria in the study area

\begin{tabular}{|l|l|l|l|}
\hline Personal knowledge & Response & Frequency & Percentage \\
\hline \multirow{2}{*}{$\begin{array}{l}\text { Are you aware of the } \\
\text { malaria disease? }\end{array}$} & Yes & 600 & 100.0 \\
\cline { 2 - 4 } & No & 0 & 0.0 \\
\hline \multirow{2}{*}{$\begin{array}{l}\text { With what name is it } \\
\text { known in your dialect? }\end{array}$} & "Iba" & 600 & 100.0 \\
\cline { 2 - 4 } $\begin{array}{l}\text { Have you suffered } \\
\text { from malaria before? }\end{array}$ & 'Ukwara' & 0 & 0.0 \\
\hline \multirow{2}{*}{$\begin{array}{l}\text { How do you know you have } \\
\text { malaria disease? }\end{array}$} & Yes & 600 & 100.0 \\
\cline { 2 - 4 } & No & 0 & 0 \\
\hline & and assumptions & 244 & 40.7 \\
\cline { 2 - 4 } & Laboratory test & & \\
\cline { 2 - 4 } & Body weakness & 300 & 50.0 \\
\cline { 2 - 4 } & By dreaming & 80 & 13.3 \\
\cline { 2 - 4 } & Yellowish eyes & 60 & 10.0 \\
\hline
\end{tabular}


A total of $502(83.7 \%)$ answered correctly that malaria is transmitted through the bites of the female Anopheles mosquito while $24(4.0 \%)$ of the respondents do not know the route of transmission of the malaria disease (Table 8). The respondents had significantly high knowledge of malaria transmission $(\mathrm{P}<0.05$; Chi-square $=1774.476 ; \mathrm{P}<0.000)$.

All the $600(100.0 \%)$ of the respondents gave the correct symptoms of malaria disease as body weakness, headache and hotness of the body (Table 9). The respondents' knowledge on the symptoms of the malaria disease were statistically significant $(\mathrm{P}<0.05$; Chi-square = 3,871.233; $\mathrm{P}<0.000)$.

Table 8 Knowledge of respondents on the transmission of the malaria parasite in the study area

\begin{tabular}{|l|c|c|}
\hline Knowledge of malaria & $\begin{array}{c}\text { Number of } \\
\text { response }\end{array}$ & Percentage \\
\hline Heredity & 30 & 5.0 \\
\hline Mosquito bite & 502 & 83.7 \\
\hline Drinking dirty water & 345 & 57.5 \\
\hline Eating too much oil & 280 & 46.7 \\
\hline Fatty food and meat & 156 & 26.0 \\
\hline Staying in a dirty environment & 322 & 53.6 \\
\hline Stagnant water around homes & 391 & 65.2 \\
\hline Poor feeding & 131 & 21.8 \\
\hline Working long hours under hot sun & 205 & 34.2 \\
\hline Evil spirit/Witchcraft/ Demons & 101 & 16.8 \\
\hline Too much bad blood & 213 & 35.5 \\
\hline Wet and cold conditions & 192 & 32.0 \\
\hline Working under heavy rain & 180 & 30.0 \\
\hline Eating raw food & 160 & 26.7 \\
\hline Don't know & 24 & 4.0 \\
\hline
\end{tabular}

Table 9 Knowledge of respondents on the symptom of malaria disease in the study area

\begin{tabular}{|l|c|c|}
\hline Symptom of malaria & Number of response & Percentage \\
\hline Body weakness & 600 & 100.0 \\
\hline Headache & 600 & 100.0 \\
\hline Hotness of the body/fever/high temperature & 600 & 100.0 \\
\hline Stomach ache & 35 & 5.8 \\
\hline Yellowish eyes & 370 & 61.7 \\
\hline Joint pains & 387 & 64.5 \\
\hline Yellowish urine & 345 & 57.5 \\
\hline Loss of appetite & 445 & 74.2 \\
\hline Vomiting & 415 & 69.7 \\
\hline Body pains & 390 & 65.0 \\
\hline Coldness of the body & 255 & 42.5 \\
\hline
\end{tabular}




\begin{tabular}{|l|c|c|}
\hline Bitterness in the mouth & 485 & 80.8 \\
\hline Weakness of the mouth & 411 & 68.5 \\
\hline Oil in the face after sleep & 45 & 7.5 \\
\hline Shivering & 461 & 77.5 \\
\hline Funny dreams & 335 & 55.8 \\
\hline Dull appearance & 366 & 61.0 \\
\hline Crying among Children & 240 & 40.0 \\
\hline Reduction in weight & 399 & 66.5 \\
\hline Rashes around the corner of the mouth & 350 & 58.3 \\
\hline Cracking/tearing of lips & 283 & 47.2 \\
\hline Don't know & 31 & 5.2 \\
\hline
\end{tabular}

The knowledge of respondents' on the methods of preventing malaria disease is shown in Table 10. All the 600 (100.0\%) respondents had common preventive methods of fixing nets on the windows, cleaning the environment and removing stagnant waters and spraying insecticides inside houses to kill the malaria vectors. The respondents' attitude on the preventive measures against the malaria disease was statistically significant $(\mathrm{P}<0.05$; Chi-square $=2,570.367 ; \mathrm{P}<$ $0.000)$.

Table 10 Respondents' response on the method of malaria disease prevention

\begin{tabular}{|l|c|c|}
\hline Preventive measure & $\begin{array}{c}\text { Number of } \\
\text { response }\end{array}$ & Percentage \\
\hline Net on windows and doors & 600 & 100.0 \\
\hline Clean environment removing stagnant waters & 600 & 100.0 \\
\hline Spraying insecticides inside houses & 600 & 100.0 \\
\hline Sleeping under insecticide-treated nets & 490 & 81.7 \\
\hline Avoiding oily foods & 222 & 37.0 \\
\hline Drinking clean water & 247 & 41.2 \\
\hline Eating balanced diets & 155 & 25.8 \\
\hline Clearing of gutters & 550 & 91.7 \\
\hline Covering of water containers in and around homes & 420 & 70.0 \\
\hline Closing doors in the evening & 440 & 73.3 \\
\hline Wearing protective clothing & 485 & 80.8 \\
\hline Filling potholes around homes & 365 & 60.8 \\
\hline Personal prayers & 332 & 55.3 \\
\hline Clearing of bushes around our homes & 555 & 92.5 \\
\hline Placing of herbs on the windows & 242 & 40.3 \\
\hline
\end{tabular}

The treatment practices of the malaria disease by the respondents in the study area were shown below in Table 11 . Among the 600 persons interviewed, $258(43.0 \%)$ buy their treatment drugs from vendors in the market, $490(81.7 \%)$ buy drugs from patent medicine shops, $524(87.3 \%)$ use herbs such as Neem plants (Dogoyaro) and Moringa plants (Okweoyibo) in the treatment of malaria. A total of 490 (81.7\%) said they visit a medical doctor at the hospital for 
treatment when sick with malaria while $272(45.3 \%)$ use other local concoctions to treat malaria. The differences in the responses on respondents' treatment practices of the malaria disease were statistically significant $(\mathrm{P}<0.05$; Chi-square 1,312.946; $\mathrm{P}<0.000$ ). The results from the FGDs of both men and women showed that the majority of the people especially those from the low-income class buy drugs from patent medicine stores.

Table 11 Practice of respondents on the treatment of malaria in the study area

\begin{tabular}{|l|c|c|}
\hline Treatment method & Number of response & Percentage \\
\hline Buy drugs from vendors in the market & 258 & 43.0 \\
\hline Buy drugs from patent medicine shops & 490 & 81.7 \\
\hline $\begin{array}{l}\text { Using herbs Neem plants (Dogoyaro), Moringa plants (Okwe } \\
\text { Oyibo) }\end{array}$ & 524 & 87.3 \\
\hline Visiting a hospital & 490 & 81.7 \\
\hline Avoiding oily foods & 405 & 67.5 \\
\hline Taking lots of fruits & 380 & 63.3 \\
\hline Using local concoctions & 272 & 45.3 \\
\hline Do nothing & 30 & 5.0 \\
\hline
\end{tabular}

Table 12 showed the orthodox drugs used in the treatment of malaria disease in the study area. On the drug of choice, 335 (55.8\%) of the participants use/take artemisinin-based combinations such as Coartem, Artemether, 210 (35.0\%) use sulfonamide - pyrimethamine (Amalar, Fansidar Malareich et Cetra), 125 (20.8\%) use Amoxil. Surprisingly, 306 $(51.0 \%)$ take Chloroquine. Statistical analysis revealed a significant difference $(\mathrm{P}<0.05$; Chi-square $=113.047$; $\mathrm{p}$-value $=0.000)$.

Table 12 Orthodox drug used in the treatment of malaria disease in the study area

\begin{tabular}{|l|c|c|}
\hline Drug & Frequency & \% frequency \\
\hline Chloroquine & 306 & 51.0 \\
\hline $\begin{array}{l}\text { Sulphunamide-pyrimethamine } \\
\text { (fansidar, amalar) }\end{array}$ & 210 & 35.0 \\
\hline Amoxil & 180 & 30.0 \\
\hline $\begin{array}{l}\text { Artemisinin } \\
\text { combined therapy } \\
\text { (coartem, artemeter) }\end{array}$ & 335 & 55.8 \\
\hline
\end{tabular}

The factors that determine the choice of the drug by the respondents in the study area are shown in Table 13 . From the Table, the factor with the highest frequency was the cost of drugs 354 (59.0\%) while the least factor was an adverse reaction to drugs 33 (5.5\%). The other responses in the order of magnitude were as follows: cost and effectiveness of drugs 270 (45.0\%) and availability of drugs 204 (34.0\%). Analysis of data showed that there was a significant difference $(\mathrm{P}<0.05$; Chi-square $=402.747$; $\mathrm{p}$-value $=0.000)$. 
Table 13 Factor determining the choice of the drug by the respondent in the study area

\begin{tabular}{|l|c|c|}
\hline Factor & Frequency & \% frequency \\
\hline Cost of drug & 354 & 59.0 \\
\hline Cost and effectiveness of drug & 270 & 45.0 \\
\hline Availability of drug & 204 & 34.0 \\
\hline Adverse reaction & 33 & 5.5 \\
\hline
\end{tabular}

The herbal remedies in the treatment of malaria infection by the respondent in the study area are shown in Table 14 . The four most important herbal remedies in the magnitude of importance and drug effectiveness were as follows: $A$. indica $(71.7 \%)$, M. oleifera (45.0\%), A. sativum (44.0\%) and Z. officinale (40.0\%). Statistical analysis of the observed differences is significant $(\mathrm{P}<0.05$; Chi-square $=516.925$; $\mathrm{p}$-value $=0.000)$. On the use of herbs and herbal preparation, an old woman of sixty years old and a farmer were of the view that the use of herbs is the best treatment measure for malaria. She thus stated "anytime I feel weak, I suspect that malaria and I will quickly go into the bush and collect Dogoyaro/Iba shutup Moringer, lime and garlic and cook for thirty minutes. I use it for a hot bath and also drink it morning and night. By the time third day, the disease is gone".

Table 14 Herbal remedy in the treatment of malaria infection by the respondent in the study area

\begin{tabular}{|c|c|c|c|c|c|}
\hline Scientific name & Common name & Local name & Frequency & $\%$ frequency & Ranking \\
\hline Azadiracta indica & Neem & 'Iba shut up' & 430 & 71.7 & $1^{\text {st }}$ \\
\hline Mangifera indica & Mango & 'Mangoro' & 182 & 30.3 & $10^{\text {th }}$ \\
\hline Cymobopogon citratus & Lemon grass & "Achara ehi" & 202 & 33.7 & $8^{\text {th }}$ \\
\hline Carica papaya & Pawpaw & 'Okwuru oyibo' & 236 & 39.3 & $5^{\text {th }}$ \\
\hline Citrus aurantiiffoia & Lime & 'Oroma Nkirisi' & 210 & 35.0 & $6^{\text {th }}$ \\
\hline Ananas comosus & Pineapple & 'Akwu Oro' & 198 & 33 & $9^{\text {th }}$ \\
\hline Zingiber officinale & Ginger & & 240 & 40.0 & $4^{\text {th }}$ \\
\hline Allium sativum & Garlic & "Ahenhea" & 264 & 44.0 & $3^{\text {rd }}$ \\
\hline Amygdalina & Bitter leaf & "Onugbu” & 210 & 35.0 & $6^{\text {th }}$ \\
\hline Psidium guajava & Guava & 'Gova' & 180 & 30.0 & $11^{\text {th }}$ \\
\hline Persea Americana & Avocado & 'Ube Oyibo' & 133 & 22.2 & $14^{\text {th }}$ \\
\hline Moringa oleifera & Moringa & 'Okwe Oyibo' & 270 & 45.0 & $2^{\text {nd }}$ \\
\hline \multirow[t]{2}{*}{ Gnetum } & & 'Utazi' & 144 & 24.0 & $13^{\text {th }}$ \\
\hline & Black African pepper & 'Uziza' & 148 & 24.7 & $12^{\text {th }}$ \\
\hline
\end{tabular}

\section{Discussion}

Malaria is an endemic and life-threatening disease in this part of the world. This study presents a $74.2 \%$ prevalence of malaria infection among the study population which is lower than 77.6\% reported by Igwe [20] from Enugu, South-East Nigeria. The high prevalence of malaria (74.2\%) in the blood samples examined was quite worrisome. The epidemiology of malaria is, however, determined by many factors including parasite virulence, host immunity and environmental factors [21]. A tilt in any direction may favour or decrease malaria prevalence. Anambra State is in the tropical rainforest and it is also traversed by many streams, rivers, with extensive freshwater swamps and humid tropical climate that favour the breeding of mosquito species and rapid development of the parasites. This is a reflection of the high rate of asymptomatic malaria parasitaemia in endemic malaria regions of which Anambra State is one. The prevalence obtained in this study was lower than the prevalence of $76.8 \%$ obtained in Okada Edo State [22], 77.4\% in Owerri Imo State [14], 80.5\% obtained from Ota, Ogun State [23], 85.5\% and 75.0\% obtained from Okigwe and Owerri, respectively [24], but higher than 73.0\% obtained from Ikwuano, Abia State [25]. The prevalence, 
intensity and regularity of malaria differ from location to location depending on factors such as rainfall pattern and proximity of human dwelling places to vector breeding sites among others [26]. The relatively high prevalence of malaria in this study could also be attributed to non-challant attitudes to malaria. It may also be because only those who were symptomatic were the ones involved in this study. Other determinant factors from KAP studies include protective and preventive measures, a poor drainage system that characterizes most communities in Anambra State including the capital territory. More so, the undulating topography nature of some places in Anambra State especially the riverine/coastal areas of Anambra East and West LGAs, swampy areas of Orumba North and South LGAs, Ogbaru LGA allow water collection in the depressions and freshwater swamps ensures constant availability of breeding grounds for mosquito vectors in the state vis-à-vis a high rate of man-fly contact thereby exposing the subjects to regular malaria infections.

The study also revealed a significant variation in malaria prevalence among the different hospital locations used for the study. A similar observation was also reported in children by Ukibe et al. [27]. This variation in prevalence may be attributed to the different environmental factors existing in the areas where the study was conducted even though these factors were not investigated by the present study. The level of environmental sanitation, as well as the state of infrastructural development, may vary between the different study locations thus causing a difference in the level of malaria transmission and infection.

The majority of the subjects studied had mild malaria 1,569 (83.0\%), few had moderate infection 224 (11.8\%) and very few had a heavy infection. Miller et al. [28] observed that immunity to malaria infection develops after prolonged and repeated infections and subsequent infections cause no symptoms or are of much less severity. Anambra State is in the malaria-endemic region of Nigeria and these infected subjects might be in various stages of immunity in their lives due to repeated infections with malaria parasites. This may have accounted for the high number of mild malaria infections when compared to moderate and heavy infections. Thomas et al. [29] described stable endemic malaria as a situation where members of a holo-endemic population remain asymptomatic even with considerably high levels of malaria parasitaemia. Part of this may be the reason for the above result of the malaria intensity.

Malaria infection was observed in all the senatorial zones in Anambra State suggesting endemicity of the disease irrespective of the fact that some of the participants were healthy. This result also indicates that malaria transmission is widespread in Anambra State, probably because the ecological and climatic conditions are very suitable for easy transmission of malaria in the study area. Such clustering is consistent with the observed tendency for Anopheles mosquitoes to over-disperse. The high prevalence of malaria in the Anambra North senatorial zone could be attributed to a poor level of sanitation. Littering the environment with cans and tins, empty containers and bottles tend to provide breeding sites for malaria vectors. The environment is surrounded by water and vegetation which are natural breeding sites for mosquito vectors. Rainfall during the wet season of the year also provides water in potholes, gutters, drainage systems, footprints and small ponds in which mosquitoes can breed. This wide range of differences may be attributed to the differences in climatic factors which promote the breeding of mosquitoes and also to human behavioural patterns and immunity which enhances susceptibility of people to infections. The population of the zone is large and encourages regular vector-man contact.

Malaria infection was detected in both males and females who participated in the study with the females having a slightly higher prevalence $1,013(77.9 \%)$ than males 878 (70.0\%). Although the females had a slightly higher prevalence than males, the difference was not statistically significant. This is consistent with the findings of Mbanugo and Ejims, [14] who observed a relatively higher malaria prevalence of $31.2 \%$ among females than their males' counterparts who had a prevalence of $22.7 \%$. Also, Oparaocha [25] observed that non-clinically ill females showed significantly higher malaria prevalence of $64.0 \%$ than their male counterparts (60.9\%) at Ikwuano, Abia State. Similarly, Warren and Mahoney [30] reported so. However, the findings of this research contrast with the findings of the following: Pelletier et al. [31], Afolabi et al. [32] and [24]. Females often stay out late during mosquito-biting hours carrying out domestic activities. Again, nowadays females wear skimpy dresses that leave most of their bodies uncovered (trendy and modern wearing style) thereby exposing themselves to mosquito bites which eventually results in malaria infection. It could also be that males have better immunity to malaria infection due to proper nutritional standards and prompt treatment on the slightest episode of the disease. Asides, females especially during pregnancy and reproductive age are more vulnerable to malaria attacks due to immune suppression [33].

Malaria infection was observed in all the age groups in this study, with the age group 31 - 40 years having the highest prevalence of malaria (93.4\%) and the least among those that were more than sixty years (59.7\%). It was noted that people in the older groups apply preventive measures against mosquito bites as a result of their knowledge of the mode of transmission. Immunity in the younger groups is low but as the age increases, stronger immunity for the disease is built up as a result of frequent exposure to the ailment, hence low prevalence among the older groups. The 
finding of this study contradicts the findings of Mbanugo and Ejims [14], Abdullahi et al. [34], WHO [35], and Askling et al. [36] reported the highest prevalence of malaria among those less than ten years old. Malaria tends to affect children and pregnant mothers, especially in rural areas.

Malaria was detected in all the occupational groups studied with the highest prevalence of $83.4 \%$, among traders and the least prevalence of $65.0 \%$ among artisans. The high prevalence of malaria among traders could be attributed to poor behavioural attitudes that tend to increase malaria transmission. This is in line with the findings of Ejezie [37] who observed that a significantly high prevalence of Plasmodium infection among low paid, industrial or unskilled workers /unemployed than in a high category like civil servants. Similarly, Ejezie [37] noted that in addition to abundant breeding sites in the study area, ignorance, poverty, unsanitary conditions, poor behavioural attitudes, and inadequate planned socio-economic projects tend to increase malaria transmission. The finding of this study contradicts the findings of Ahmed et al. (2001) [38] who reported that poor farmers had the highest prevalence because of their inadequate facilities and financial constraints making them unable to engage in malaria preventive and control strategies.

In the same vein, malaria infection was detected in all the educational groups with the highest prevalence (83.0\%) among those who had no form of formal education and the least prevalence (59.1\%) among those with tertiary education. Education improves general awareness of disease causation and prevention. It could be that those who have a degree or tertiary education had a better understanding of how to protect themselves from a mosquito bite and disease transmission. This study corroborates with the findings of Ugha et al. [39] who obtained the least prevalence of malaria among those with tertiary education and attributed it to their high awareness as a result of educational background. Ugha et al. [39] observed that those with primary education and non-formal education attributed malaria infection to working under the sun or long hours of exposure to heat and eating of too much oil and concluded that the poor perception of malaria infection by rural dwellers is unhelpful in the prevention and co ntrol of malaria. The high prevalence among those with non-formal education could be attributed to a lack of knowledge about malaria infection and prevention.

\section{Conclusion}

Overall, results showed that malaria is endemic in Anambra State and is associated with some levels of haematological and biochemical abnormalities. The level of education and the number of information sources were the determining factors. Peoples' knowledge must be reinforced especially on diagnostic methods and therapeutic aspects. Organized awareness campaigns on malaria in addition to lectures and spreading key messages through social media and students' associations are suggested.

\section{Compliance with ethical standards}

\section{Acknowledgements}

The authors will like to appreciate the Medical Directors and the staff of the health facilities used for the study.

\section{Statement of informed consent}

The study was approved by the Ethical Committee of Anambra State Ministry of Health. Advocacy visit to the State Ministry of Health with a letter of introduction from the Head of Department of Biological Sciences, Chukwuemeka Odimegwu Ojukwu University Uli Campus was used to obtain the approval for the study. Advocacy visits with a copy of the approval letter from the Ministry of Health to the Medical Directors of the health facilities used for the study were used to get the support and cooperation of the health facilities and their staff.

\section{References}

[1] Boraschi D, Abebe n, Alemayehu M, Aseffa A, Chiodi F, Chisi J, Del Prete G. Immunity against HIV/AIDS, malaria, and tuberculosis during co-infections with neglected infectious diseases: recommendations for the European Union research priorities. PLoS Neglected Tropical Disease. 2008; 2(6): e255.

[2] Kantele A, Jokiranta TS. Review of cases with the emerging fifth human malaria parasite, Plasmodium knowlesi. Clinical Infectious Diseases. 2011; 52: 1356-1362. 
[3] Onyido AE, Obinatu SC, Umeanaeto PU, Obiukwu MO, Egbuche MC. Malaria prevalence and mosquito vector abundance in Uli Town, Ihiala Local Government Area, Anambra State, Nigeria. African Journal of Biomedical Research. 2011; 14: 175-182.

[4] World Health Organization. A global strategy for Malaria control, Geneva. 2020.

[5] World Health Organisation (WHO). Malaria epidemics: Forecasting, prevention, early detection and controlfrom policy to practice. Geneva. 2004

[6] World Health Organization. World malaria report fact sheet. 2012.

[7] Ekwebene 0. Malaria: prevalence and control infants and pregnant women: Nigeria. 2015.

[8] Federal Ministry of Health (FMOH) National Malaria and Vector Control Division. Federal Ministry of Health Abuja Nigeria. 2001; 1-8.

[9] Uzochukwu BS, Ezeke OP, Onwujekwe OE, Sibendue FT. Malaria treatment service in Nigeria. A review. Nigerian Medical Journal. 2010; 51: 14-119.

[10] Onwujekwe OE, Chima RI, Okonkwo PO. Economic Burden of Malaria Illness versus That Of A Combination Of Other Illness. A Study in Five Malaria Holo-Endemic Communities. Health Policy. 2000; 54: 143-159.

[11] Muwonge H, Kikomeko S, Sembajjwe LF, Seguya A, Namugwanya C. How reliable are hematological parameters in predicting uncomplicated Plasmodium falciparum malaria in an endemic region. Tropical Medicine. 2013; 10(11): 673-798.

[12] Abuaku B, Duah N, Quaye L, Quashie N, Koram K. Therapeutic efficacy of @artemether-lumefantrine combination in the treatment of uncomplicated malaria among children under five years of age in three ecological zones in Ghana. Malaria Journal. 2012; 11: 388 - 401.

[13] Douglas NM, Anstey NM, Buffet PA, Poespoprodjo JR, Yeo TW, White NJ. The anaemia of Plasmodium vivax malaria. Malaria Journal. 2012; 40(5): 405 - 421.

[14] Mbanugo JI, Ejims DO. Plasmodium infection in children aged 0-5 years in Awka Metropolis, Anambra State, Nigeria. Nigerian Journal of Parasitology and Public Health. 2000; 21: 55-59.

[15] World Health Organisation (WHO). Malaria situation. In:Weekly Epidemiological Record. No. 2015; 45(90): 609616.

[16] Schmidt GD, Roberts LS. Phylum Apicomplexa: Malaria organisms and piroplasm. In: L. S. Roberts and J. Janovy, Jr. (Eds.), Foundations of Parasitology, 9th Edition. New York: McGraw-Hill, Inc. 2013; 147-173.

[17] Kolawole OM, Kana SN. Hepattis B virus and malaria co-infection causing significant changes in haematological and liver function indices in a cohort of subjects in Ilorin, Nigeria. International Journal of Infectious Diseases. 2018; 5(3): e81528.

[18] Cheesbrough M. District laboratory in tropical countries. Part 1. Cambridge University Press. $2005 ; 246$ - 250.

[19] Kolawole OM, Adu FD, Agbede 00, Oni AA, Bakare RA. Epidemiological Patterns of Human Immunodeficiency Virus and Herpes Simplex Virus Co-infection in Ibadan, Nigeria. African Journal of Biomedical Research. 2008; 11: 204-6.

[20] Igwe NM, Joannes UO, Chukwuma OB, Chukwudi OR, Olisaemeka EP, Maryrose AU, Joseph A. Prevalence and parasite density of asymptomatic malaria parasiteamia among unbooked paturients at Abakaliki, Nigeria. Journal of Basic Clinical and Reproductive Science. 2014; (3): 44-8.

[21] Eneanya CI. Seasonal variation in Malaria Episodes among Residents of udi, a semi-urban community in South East Nigeria. Nigerian Journal of Parasitology. 1988; 19(1): 39 - 43.

[22] Otajevwo FD. Prevalence of malaria parasitaemia and its association with ABO blood group students of Igbinedion University Okada, Nigeria. British Journal of Medicine and Medical Research. 2013; 3: 1164-1177.

[23] Olasehinde GI, Ajayi AA. Taiwo SO, Adekeye BT, Adeyeba OA. Prevalence and management of falciparum malaria among infants and children in Ota, Ogun State, Southwestern, Nigeria. African Journal of Clinical and Experimental Microbiology. 2008; 11(3): 159 - 163.

[24] Ukpai OM, Ajoku EI. The prevalence of malaria in Okigwe and Owerri Areas of Imo State. Nigerian Journal of Parasitology and Public Health. 2001; 22: 43-48. 
[25] Oparaocha ET. The impact of haemoglobin level and concomitant infections on malaria parasitaemia and onset of fever during malaria attack at Ikwuano Local Government Area of Abia State, Nigeria, The Nigerian Journal of Parasitology. 2003; 24: 25-32.

[26] Onyido AE, Ezike VI, Nwosu EO, Ozumba NA, Ikpeze O0, Obiukwu MO, Amadi ES. Crepuscular man-biting mosquitoes of a tropical zoological garden in Enugu South-eastern Nigeria. Internet Journal of Parasitic Diseases. 2009; 4(1): 1-9.

[27] Ukibe SN, Mbanugo JI, Ukibe NR. Prevalence of malaria and increasing spleen rate in children aged 0-13 years in Awka South Local Govern,ent Area of Anambra State. Nigeria Journal of Environmental Health. 2008; 5(2): 6469.

[28] Miller FP, Rong B, Till H, Eggelte TA, Beck S, Gyasi-Sarpong C, Thompson WN, Bienzle U. Submicroscopic Plasmodium falciparum infections in pregnancy in Ghana. Tropical Medicine of International Health. 2007; 5: 167-173.

[29] Thomas CJ, Davies G, Dunn CE. Mixed picture for changes in stable malaria distribution with future climate in Africa. Trends in Parasitology. 2004; 20: 216-220.

[30] Mahoney FJ. Update on diagnosis, management, and prevention of hepatitis B virus infection. Clinical Microbiology Review. 1999; 12: 351-66.

[31] Pelletier H, Schellenberg JA, Mukasa O, Nathan R, Abdulla S, Mponda H, Tanner M, Lengeler C, Obrist B. Introducing insecticide-treated nets in the Kilombero Valley, Tanzania: the relevance of local knowledge and practice for an information, education and communication (IEC) campaign. Tropical Medicine of International Health. 1999; 6: 614-623.

[32] Afolabi MB, Ogunshile SF, Onwujekwe ID, Sanyolu ON, Williams OF, Awolowo OA. Malaria, malnutrition and other illnesses among urban pre -school children in Nigeria. Nigerian Quarterly Journal of Hospital Medicine. 2001; 17(4): 345-348.

[33] Aribodor DN, Njoku OO, Eneanya CI, Onyali IO. Studies on the prevalence of malaria and management practices in Azia Community in Ihiala Local Government Area, Anambra State, South East Nigeria. Nigerian Journal of Parasitology. 2003; 24: 33 - 38.

[34] Abdullahi K, Abubakar U, Adamu T, Daneji AI, Aliyu RU, Jiya N, Ibraheem MTO, Nata'ala SU. Malaria in Sokoto, North Western Nigeria. African Journal of Biotechnology. 2009; 8(24): 7101 - 7105.

[35] World Health Organisation. Advanced immunization management. Hepatitis. Fact sheet No. 2005.

[36] Askling HH, Nilsson J, Tegnell A. Malaria risk in travellers. Emerging Infectious Diseases. 2005; 11(3): 436 - 441.

[37] Ejezie GG. The Nigeria environment and parasitic infections. Folia parasites (PRAHA). 1990; 30: 80 - 95.

[38] Ahmed SG, Ibrahim UA, Ibrahim G. Prevalence and clinical significance of malaria parasitaemia in blood donors in Maiduguri, Nigeria. Nigeria Journal of Parasitology. 2001; 22 (1 and 2): 29 - 34.

[39] Ugha CN, Onyido AE, Obiukwu MO, Umeanaeto PU, Egbuche MC, Obiechina IO. Stable endemic malaria in a rainforest community of Southeastern Nigeria. Nigerian Journal of Parasitology and Public Health. 2013; 6(3): 615. 